\title{
Biographical Sketch for Haybron
}

\section{Daniel M. Haybron ${ }^{1}$}

Published online: 19 March 2020

(C) The International Society for Quality-of-Life Studies (ISQOLS) and Springer Nature B.V. 2020

Dan Haybron was born next to a nuclear weapons facility, in Oak Ridge, Tennessee, a city created entirely for the purpose of making the Bomb, and hence affectionately known as "Bomb Town." His parents, physicist Ron and artist Alice Haybron, soon after moved the family to Chagrin Falls, Ohio. In Ohio, his hobbies included reading books, backyard sports, avoiding school, and munitions. (For the record, no one was ever going to use that boat.)

From 1969 until 1988, Haybron spent most of his summers shoeless in his spiritual home of Ocracoke, a remote island in North Carolina with sporadic electricity that was populated mainly by the descendants of pirates. There his life revolved around the ocean, taking most meals from the sea, sailing and keeping a wild aquarium in which he learned not to put crabs or eels. From age sixteen onward he rented a bed and worked in local restaurants, where waiting tables proved not to be among his talents. The island experience, and the contrast between that life and Ohio, left him with a bicultural perspective that was instrumental in shaping his later work in philosophy. By age ten or eleven it was apparent to him that "mainland" life was quite insane.

In 1989 he made the worst mistake of his life - at least, the worst he'll admit totrusting a Washington, DC junkyard to replace the transmission in his 1976 Peugeot, which was then left without keys or clutch — or, as far as anyone could tell, a transmission - in a Georgetown intersection. Two weeks and a summer's earnings later, he was grateful to the repair shop that took ownership of the car without even charging him. He may or may not still be wanted by the DC police but is happy to avoid the city anyway. He still wonders why a car manufacturer would use both English and metric fittings on a single hydraulic line.

Haybron's later decision to write a doctoral dissertation on the outré topic of happiness was generally regarded at the time as a far worse mistake even than a Peugeot. But first a bit more about how he got there. He graduated in 1990 with a philosophy BA from Wesleyan University and was immediately rejected by nearly every Ph.D. program he applied to, one of which took the trouble to observe that "you

Daniel M. Haybron

dan.haybron@slu.edu

1 Saint Louis University, St. Louis, MO, USA 
may be a promising candidate for study in some field, but not in philosophy as we do it [here]." Apparently the Heideggerian writing sample from a religious studies course was not a strategically wise move.

Moving to the Bay Area with his soon-to-be wife, Elizabeth-with whom he now has three children-Haybron spent two years working in the software industry, doing technical support at Intuit and working on application development standards for Oracle, and later consulting for Merrill-Lynch. Seeing little money in this "internet" thing, Haybron applied again to graduate philosophy programs and was nearly accepted by many programs but in fact only two, one inexplicably being the top-ranked philosophy department at Rutgers. So to New Jersey Dan and Elizabeth went.

After struggling to start a dissertation on the evidential status of intuitions and deciding that he'd rather eat a bag of nails than spend his life teaching metaphysics, Haybron went bodysurfing and realized that engaging with the nascent science of happiness was his calling. This allowed him to return to some basic questions that had captured his attention since his youth on the island, but also had a few drawbacks, such as tending to elicit incredulous stares. Fortunately the department at Rutgers kindly indulged Haybron's whimsy and supported the venture, with the wonderful Doug Husak supervising, while Wayne Sumner of Toronto graciously agreed to serve as a reader. Steve Stich was also a terrific mentor and had a great influence on Haybron's work.

The resulting dissertation was well-received, and prospects for the job market might have seemed good. Haybron was told he was very nearly interviewed at many places, but was in fact interviewed at only one, and offered a job at none. The second year out he secured a very agreeable one-year position at University of Arizona in Tucson, where he, Elizabeth and baby were fortunate to sublet a mountaintop resort, which unfortunately was infested with scorpions though only once did baby get hold of one. By the third year he ceased to care whether anyone wanted to give him a job and was rewarded with two attractive tenure-track offers, accepting a position in 2002 at Saint Louis University, which has proven to be a most congenial environment.

Haybron's research has focused mainly on the character of a good life, particularly happiness and well-being, from the perspective of ethics, political philosophy, and psychology. These themes structure many of his papers and his 2008 book with Oxford University Press, The Pursuit of Unhappiness: The Elusive Psychology of Well-Being. That book attempts to lay out a structure for an emerging field of "prudential psychology," and argues against the common assumption that people are generally authoritative in matters of personal welfare. The book is best known for elaborating a novel "emotional state" theory of happiness - as roughly the opposite of anxiety and depression - as distinct from traditional hedonistic and life satisfaction theories. This theory has since become one of the standard views in the philosophical literature, and figures as a key element in Haybron's "Millian hybrid" theory of well-being. The volume also contains what may be the most thorough extant discussion of the various strands of evidence that human beings do not always benefit from greater freedom of choice and tend systematically to make a wide range of serious mistakes in the pursuit of happiness. For example, driving French cars.

The 2008 book raised a pair of questions that have animated most of Haybron's subsequent work, which has centered on two book-length projects, provisionally titled Good Lives and Good Societies. The first concerns the role of happiness in the broader 
picture of a good life, which is an oddly under-theorized topic. While happiness is a central element of that picture, there are other aspects to well-being, and values other than well-being are also crucial, such as excellence, engagement with beauty, and morality. Just as modern ways of living have yielded mixed results on the happiness question, so too have they fallen short in taking seriously the role of other values like excellence and beauty, which provide our lives with much of their meaning. Some key themes of this book were introduced in Haybron's 2013 book with Oxford, Happiness: A Very Short Introduction, which has been translated into five languages to date.

The second project focuses on the social and political dimensions of well-being in light of Haybron's earlier contentions that human cognition, behavior and well-being are pervasively shaped by our social and physical context. Good Societies, and Haybron's policy-related papers to date (including works with collaborators Anna Alexandrova and Valerie Tiberius), attempt to lay philosophical foundations for wellbeing policy and the questions of legitimacy, justification, paternalism and measurement that it raises. He also hopes to make a case for policies aimed at preservation of the natural environment for its own sake, despite widespread disagreement about such matters. Haybron's research on policy matters has been greatly aided by the opportunity to engage with policymakers and advisers in several contexts, including the United Nations, Bhutan, Mexico, the OECD, and most recently a Vatican working group on science and ethics for sustainable happiness and well-being.

In 2015 Haybron was awarded a \$5.1 million grant for a three-year project, Happiness and Well-Being: Integrating Research Across the Disciplines, funded by the John Templeton Foundation and Saint Louis University. This project aimed at fostering cross-disciplinary well-being research, particularly bridging the divide between sciences and philosophy and religious thought, and funded 21 research teams around the world.

Currently Haybron's research also centers on two further projects: empirical studies of folk concepts of happiness and well-being with collaborator Markus Kneer, and validating a new measure of happiness/emotional well-being, with psychologist David Yaden. It is hoped that this scale will offer researchers and policymakers a more publicly accessible and culturally sensitive measure of the emotional aspects of wellbeing.

In 2019 Haybron was honored as the inaugural recipient of the Theodore R. Vitali C.P. Chair of Philosophy at Saint Louis University, which was made possible by a generous bequest from his colorful and much-admired colleague and former department chair Fr. Ted Vitali, who is uncommonly wise and also an excellent shot.

\section{References}

Haybron, D. M. (2013). Happiness: A very short introduction. Oxford University Press.

\section{Selected Publications}

Haybron, D. M. (2005). On being happy or unhappy. Philosophy and Phenomenological Research, 71(2), $287-317$. 
Haybron, D. M. (2007). Do we know how happy we are? On some limits of affective introspection and recall. Noûs, 41(3), 394-428.

Haybron, D. M. (2008a). The pursuit of unhappiness: The elusive psychology of well-being. Oxford University Press.

Haybron, D. M. (2008b). Happiness, the self and human flourishing. Utilitas, 20(01), 21-49.

Haybron, D. M. (2014). Adventures in assisted living: Well-being and Situationist psychology. In N. E. Snow \& F. V. Trivigno (Eds.), The Philosophy and Psychology of Character and Happiness (pp. 1-25). Routledge.

Haybron, D. M. (2016). The philosophical basis of Eudaimonic psychology. In J. Vittersø (Ed.), Handbook of Eudaimonic Well-Being (pp. 27-53). Springer.

Haybron, D. M., \& Alexandrova, A. (2013). Paternalism in economics. In C. Coons \& M. Weber (Eds.), Paternalism: Theory and Practice (pp. 157-177). Cambridge University Press.

Haybron, D. M., \& Tiberius, V. (2015). Well-being policy: What standard of well-being? Journal of the American Philosophical Association, 1(04), 712-733.

Publisher's Note Springer Nature remains neutral with regard to jurisdictional claims in published maps and institutional affiliations. 